\title{
Growth and grazing rates of the prostomatid ciliate Tiarina fusus on red-tide and toxic algae
}

\author{
Hae Jin Jeong ${ }^{1, *}$, Joo Yih Yoon ${ }^{1}$, Jae Seong Kim ${ }^{1}$, Young Du Yoo ${ }^{1}$, Kyeong Ah Seong ${ }^{2}$ \\ ${ }^{1}$ Department of Oceanography, College of Ocean Science and Technology, and \\ ${ }^{2}$ Red Tide Research Center, Kunsan National University, Kunsan 573-701, South Korea
}

\begin{abstract}
We investigated growth and grazing rates of the prostomatid ciliate Tiarina fusus when feeding on several species of red-tide and/or toxic algae (RTA). T. fusus ingested the dinoflagellates Lingulodinium polyedrum, Scrippsiella trochoidea, Heterocapsa triquetra, Prorocentrum minimum, Amphidinium carterae, and the raphidophyte Heterosigma akashiwo, but rarely consumed the dinoflagellate Ceratium fusus, and did not feed on the dinoflagellate Prorocentrum micans. T. fusus exhibited positive growth on L. polyedrum, S. trochoidea, and H. akashiwo. Specific growth rates of $T$. fusus increased rapidly with increasing density of L. polyedrum, S. trochoidea, and H. akashiwo before saturating between 500 and $1000 \mathrm{ng} \mathrm{C} \mathrm{ml}^{-1}$. Maximum specific growth rate of $T$. fusus feeding on $L$. polyedrum $\left(0.47 \mathrm{~d}^{-1}\right)$ was much higher than when feeding on $S$. trochoidea $\left(0.13 \mathrm{~d}^{-1}\right)$ or $H$. akashiwo $\left(0.10 \mathrm{~d}^{-1}\right)$. Threshold prey concentrations (where net growth $=0$ ) for L. polyedrum, $S$. trochoidea, and $H$. akashiwo were 34 to $160 \mathrm{ng} \mathrm{C} \mathrm{ml}^{-1}$. Maximum ingestion rates of T. fusus on $L$. polyedrum, $S$. trochoidea, and $H$. akashiwo were $23.4,10.2$, and $6.5 \mathrm{ng} \mathrm{C}$ predator ${ }^{-1} \mathrm{~d}^{-1}$, respectively, while maximum clearance rates were $4.5,0.2$, and $0.6 \mu l$ predator ${ }^{-1} \mathrm{~h}^{-1}$, respectively. T. fusus exhibited comparable or higher maximum growth, ingestion, and clearance rates than previously reported for the mixotrophic dinoflagellate Fragilidium cf. mexicanum or the heterotrophic dinoflagellates Protoperidinium cf. divergens and P. crassipes, when grown on the same prey species. Grazing coefficients calculated by combining field data on abundances of T. fusus and co-occurring RTA with laboratory data on ingestion rates obtained in the present study suggest that $T$. fusus sometimes has a considerable grazing impact on the populations of $H$. akashiwo.
\end{abstract}

KEY WORDS: Dinoflagellate $\cdot$ Feeding $\cdot$ Harmful algal bloom $\cdot$ Ingestion $\cdot$ Protist $\cdot$ Raphidophyte

\section{INTRODUCTION}

Algal blooms, often referred to as 'red tides', can alter the balance of food webs and cause large-scale mortalities of fish and shellfish (ECOHAB 1995). Studies of red tide formation and persistence suggest that grazing pressure may play an important role in bloom dynamics (Watras et al. 1985). In particular, grazing by microzooplankton is believed to contribute to the decline of algal blooms (Holmes et al. 1967, Eppley \& Harrison 1975). The prostomatid ciliate Tiarina fusus

*E-mail: hjjeong@kunsan.ac.kr sometimes dominates the ciliate abundance and/or biomass in many coastal (Beers \& Stewart 1969, Elbrächter 1973, Morey-Gaines 1980, Smetacek 1981, Reid et al. 1985, Tumantseva \& Kopylov 1985, Dale \& Dahl 1987, Dale 1988, Nomura et al. 1992) and oceanic waters (Mamaeva 1983, Moiseyev 1986, Sleigh et al. 1996). It is often abundant during blooms dominated by the dinoflagellate Ceratium spp. (Smetacek 1981, Nielsen 1991, Nielsen \& Kiørboe 1994) and/or the raphidophyte Heterosigma akashiwo (authors' unpubl. data), and can itself cause red tides (Dale \& Dahl 1987; maximum density $=34000$ cells $\mathrm{ml}^{-1}$ ). However, no data are available for $T$. fusus growth and grazing rates as a function of prey concentration, prey selec- 
tion, threshold prey concentrations, and grazing impact on prey populations.

To better understand the ecological role of Tiarina fusus in the planktonic community, we established a monoclonal culture of $T$. fusus and conducted experiments to examine its numerical and functional responses when grown on a variety of toxic and/or redtide algae (RTA). Our goal was to explore the predatorprey relationship between $T$. fusus and RTA by determining threshold prey concentrations, optimal prey species, and the ciliate's maximum growth, ingestion, and clearance rates. We also estimated grazing coefficients attributable to Tiarina on RTA using our data for ingestion rates and accounts of predator and prey abundances in the field samples.

Maximum growth and grazing rates of Tiarina fusus on unialgal diets are compared to literature data on mixotrophic or heterotrophic dinoflagellates and other ciliates feeding on the same prey species. Results of the present study provide a basis for understanding the potential of $T$. fusus to influence the population dynamics of RTA.

\section{MATERIALS AND METHODS}

Culture of phytoplankton prey. RTA (Table 1) were grown at $19^{\circ} \mathrm{C}$ in enriched $\mathrm{f} / 2$ seawater media (Guillard \& Ryther 1962) without silicate, under continuous illumination of $100 \mu \mathrm{E} \mathrm{m}^{-2} \mathrm{~s}^{-1}$ provided by cool white fluorescent lights. Only cultures in exponential growth

Table 1. Species of autotrophic or mixotrophic prey and predator used in the present study, listed in order of cell volume. Volume $\left(\mu^{3}\right)$ of preserved prey cells (to the nearest hundred) was calculated according to the equation: volume = $4 / 3 \pi(\mathrm{ESD} / 2)^{3}$. ESD (mean equivalent spherical diameter) was measured with a PAMAS-SVSS particle counter. Cell volume of the predator was estimated from geometrical forms after being satiated with Lingulodinium polyedrum and then starved for $1 \mathrm{~d}$. Carbon contents (ng C) per prey and predator were estimated from cell volume according to Strathmann (1967) and Putt \& Stoecker (1989), respectively. The number of cells measured (n) was $>2000$ for prey and 70 for the predator

\begin{tabular}{|lcc|}
\hline Species & $\begin{array}{c}\text { Approximate } \\
\text { volume }( \pm \mathrm{SE})\end{array}$ & $\begin{array}{c}\text { Carbon } \\
\text { content cell }\end{array}$ \\
\hline Heterosigma akashiwo & $700(8)$ & 0.11 \\
Heterocapsa triquetra & $1100(3)$ & 0.15 \\
Prorocentrum minimum & $1100(4)$ & 0.15 \\
Amphidinium carterae & $2200(16)$ & 0.27 \\
Scrippsiella trochoidea & $8300(31)$ & 0.85 \\
Prorocentrum micans & $9200(50)$ & 0.94 \\
Ceratium fusus & $11600(9)$ & 1.26 \\
Lingulodinium polyedrum & $28500(216)$ & 2.50 \\
Tiarina fusus & $25400(76)$ & 4.83 \\
\hline
\end{tabular}

phase were used for feeding experiments. The toxic dinoflagellate Amphidinium carterae (ACKS 0010) has a toxicity of $1 \mathrm{MU} / 1.3 \times 10^{8}$ cells (Jeong et al. 2001b). Carbon contents for RTA were estimated from cell volume according to Strathmann (1967).

Isolation and culture of Tiarina fusus. A $30 \mathrm{~cm}$ diameter, $20 \mu \mathrm{m}$ mesh plankton net was used to collect samples from coastal waters off Jinhae, Korea, during April 2001, when the water temperature was $17^{\circ} \mathrm{C}$. The samples were screened gently through $154 \mu \mathrm{m}$ Nitex mesh and placed in $1 \mathrm{l}$ polycarbonate (PC) bottles. Bottles were spiked with $50 \mathrm{ml}$ of $\mathrm{f} / 2$ media, and a mixture of Lingulodinium polyedrum and Scrippsiella trochoidea was added as food. Bottles were placed on a shelf and incubated at $19^{\circ} \mathrm{C}$ under continuous illumination of $10 \mu \mathrm{E} \mathrm{m}^{-2} \mathrm{~s}^{-1}$ of cool white fluorescent light. After $3 \mathrm{~d}$, aliquots of the enriched water were transferred to 6 -well tissue culture plates, and a monoclonal culture was established by 2 serial single cell isolations. Once dense cultures of Tiarina fusus were obtained, they were transferred to 500 or $1000 \mathrm{ml} \mathrm{PC}$ bottles of fresh prey every 2 or $3 \mathrm{~d}$. Experiments were conducted when a large volume of $T$. fusus culture was available.

Growth and ingestion rates. Expts 1 to 8 were designed to measure growth, ingestion, and clearance rates of Tiarina fusus, as a function of the prey concentration, when feeding on RTA.

Two days before these experiments were conducted, dense cultures of Tiarina fusus growing on Lingulodinium polyedrum were transferred into $11 \mathrm{PC}$ bottles containing low concentrations of the target prey. This was done to acclimate the predator to the target prey and minimize possible residual growth resulting from ingestion of prey during batch culture. The bottles were filled to capacity with filtered seawater and placed on a shelf to incubate as above, except that illumination was provided on a 12:12 h light:dark cycle. The abundances of $T$. fusus and prey were determined by enumerating cells in three $1 \mathrm{ml}$ Sedgwick-Rafter counting chambers (SRCs).

For Expts 1 to 8, initial concentrations of Tiarina fusus and target prey were established using an autopipette to deliver predetermined volumes of known cell concentrations to the bottles. Triplicate $80 \mathrm{ml}$ PC experiment bottles (mixtures of predator and prey) and triplicate control bottles (prey only) were set up at each predator-prey combination. Triplicate control bottles containing only $T$. fusus were also established at 1 predator concentration. Ten $\mathrm{ml}$ of $\mathrm{f} / 2$ media were added to all bottles, which were then filled to capacity with freshly filtered seawater and capped. To determine actual predator and prey densities at the beginning of the experiment and after 24,48 , and $72 \mathrm{~h}$ incubation, $5 \mathrm{ml}$ aliquots were removed from each 
bottle and fixed with 5\% Lugol's solution, and all Tiarina and all or $>200$ prey cells in three $1 \mathrm{ml}$ SRCs were enumerated. The range of the actual predator densities at the beginning of Expts 1 to 8 was 4 to 90 Tiarina $\mathrm{ml}^{-1}$. Prior to taking subsamples, the condition of $T$. fusus and its prey was assessed with a dissecting microscope. The bottles were filled again to capacity with freshly filtered seawater, capped, and placed on a shelf under the environmental conditions described above. Dilution of the cultures associated with refilling the bottles was considered in calculating growth and ingestion rates.

The specific growth rate of Tiarina fusus $\left(\mu, \mathrm{d}^{-1}\right)$ was calculated by averaging the instantaneous growth rates (IGR) for each sampling interval, calculated as:

$$
\operatorname{IGR}=\frac{\ln \left(S_{t^{2}} / S_{t^{1}}\right)}{t_{2}-t_{1}} \times 24
$$

where $S_{t^{1}}$ and $S_{t^{2}}=$ the concentration of $T$. fusus at consecutive samplings. The final $t_{2}$ for calculation was $48 \mathrm{~h}$, which provided the highest specific growth rate.

Data for Tiarina fusus growth rate were fitted to a Michaelis-Menten equation:

$$
\mu=\frac{\mu_{\max }\left(x-x^{\prime}\right)}{K_{\mathrm{GR}}+\left(x-x^{\prime}\right)}
$$

where $\mu_{\max }=$ the maximum growth rate $\left(\mathrm{d}^{-1}\right) ; x=$ prey concentration (cells ml-1 or $\mathrm{ng} \mathrm{C} \mathrm{ml}^{-1}$ ), $x^{\prime}=$ threshold prey concentration (the prey concentration where $\mu=$ $0), K_{\mathrm{GR}}=$ the prey concentration sustaining $1 / 2 \mu_{\max }$. Data were iteratively fitted to the model using DeltaGraph $^{\circledast}$ (Delta Point).

Ingestion and clearance rates were calculated using the equations of Frost (1972) and Heinbokel (1978). Incubation time for calculating ingestion and clearance rates was the same as for estimating growth rate. Ingestion rate data were fitted to a Michaelis-Menten equation:

$$
\mathrm{IR}=\frac{I_{\max }(x)}{K_{\mathrm{IR}}+(x)}
$$

where $I_{\max }=$ the maximum ingestion rate (cells predator $^{-1} \mathrm{~d}^{-1}$ or ng C predator $\left.{ }^{-1} \mathrm{~d}^{-1}\right) ; x=$ prey concentration (cells $\mathrm{ml}^{-1}$ or $\mathrm{ng} \mathrm{C} \mathrm{ml}^{-1}$ ), $K_{\mathrm{IR}}=$ the prey concentration sustaining $1 / 2 I_{\max }$.

Attack ratio and successful capture. Expt 9 was designed to determine attack ratio (i.e. number of attempted captures relative to number of physical contacts between predator and prey) and successful capture (i.e. number of prey ingested relative to number of attempted captures) by monitoring the behavior of Tiarina fusus in the presence of different RTA. Attempted captures represented physical contacts where the predator remained associated with the prey for longer than $2 \mathrm{~s}$. Successful captures were attacks that resulted in the prey being ingested. Individual $T$. fusus cells starved for $1 \mathrm{~d}$ were transferred to a Petri-dish (49 mm in diameter) containing unialgal prey (Lingulodinium polyedrum, Scrippsiella trochoidea, or Prorocentrum micans) with concentrations of 1250 to $1269 \mathrm{ng} \mathrm{C} \mathrm{ml}^{-1}$, and each predator was tracked under a dissecting microscope until it successfully engulfed a prey cell or until $1 \mathrm{~h}$ had elapsed. For each prey species, the number of predator-prey encounters, attempted prey captures, and ingested prey were recorded for $8 \mathrm{~T}$. fusus (i.e. 8 replicates). Heterosigma akashiwo cells were too small to clearly detect predator encounters and/or attacks.

Swimming speed. Swimming speeds of 2 prey species (Heterosigma akashiwo and Heterocapsa triquetra) previously unreported and Tiarina fusus were measured at $19^{\circ} \mathrm{C}$ using a video analyzing system. For each species, aliquots from a dense culture were added to multiwell plates and allowed to acclimate for $30 \mathrm{~min}$. Swimming was then observed and recorded at $40 \times$, with mean and maximum swimming velocity analyzed for fast-swimming cells that exhibited straight linear paths. Average swimming speed was calculated based on the linear displacement of cells in $1 \mathrm{~s}$ during single-frame playback. Swimming speeds of more than 10 cells were measured for each species.

Grazing impact. We estimated grazing coefficients attributable to Tiarina on RTA by combining field data on abundances of Tiarina and prey with ingestion rates of the predator on the prey obtained in the present study.

Grazing coefficients $\left(g, \mathrm{~d}^{-1}\right)$ were calculated as:

$$
g=(1 / \Delta t)\left\{\ln \left[C_{\mathrm{i}} /\left(C_{\mathrm{i}}-C_{\mathrm{e}}\right)\right]\right\}
$$

where $\Delta t(\mathrm{~d})$ is a time interval, $C_{\mathrm{e}}\left(\right.$ cells $\left.\mathrm{ml}^{-1}\right)$ is the number of prey cells eaten by the Tiarina population in $1 \mathrm{ml}$ of seawater in $1 \mathrm{~d}$, and $C_{\mathrm{i}}\left(\right.$ cells ml $\left.{ }^{-1}\right)$ is the initial prey cell concentration on a given day. The values of $C_{\mathrm{e}}$ were calculated as:

$$
C_{\mathrm{e}}=\operatorname{PIR} \times 1 \mathrm{~d}=\mathrm{IR} \times G \times 1 \mathrm{~d}
$$

where PIR is the population ingestion rate of Tiarina on a RTA in $1 \mathrm{ml}$ of seawater (prey eaten $\mathrm{ml}^{-1} \mathrm{~d}^{-1}$ ), IR is the ingestion rate (prey eaten Tiarina ${ }^{-1} \mathrm{~d}^{-1}$ ) of Tiarina on a RTA, and $G$ is the abundance (cells $\mathrm{ml}^{-1}$ ) of Tiarina on the same day as $C_{\mathrm{i}}$.

\section{RESULTS}

\section{Feeding process and prey species}

Tiarina fusus feeds on RTA by engulfment and can contain several prey cells simultaneously. Among RTA offered as prey, T. fusus ingested Lingulodinium poly- 


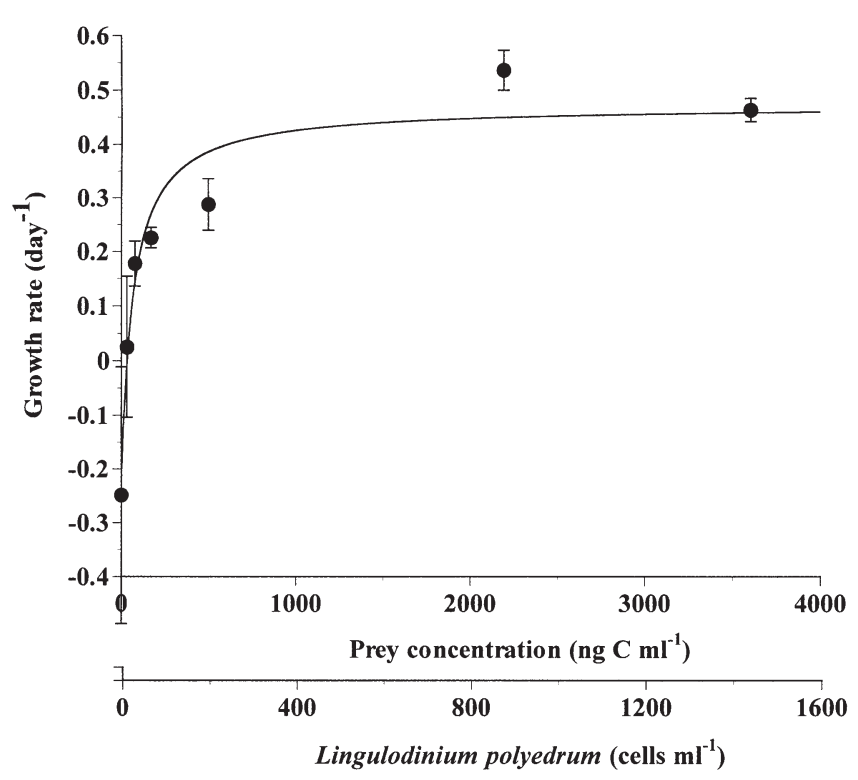

Fig. 1. Tiarina fusus. Specific growth rates on Lingulodinium polyedrum as a function of mean prey concentration. Symbols represent treatment means $\pm 1 \mathrm{SE}$. The curves are fitted by a Michaelis-Menten equation (Eq. 2) using all treatments (see Table 2)

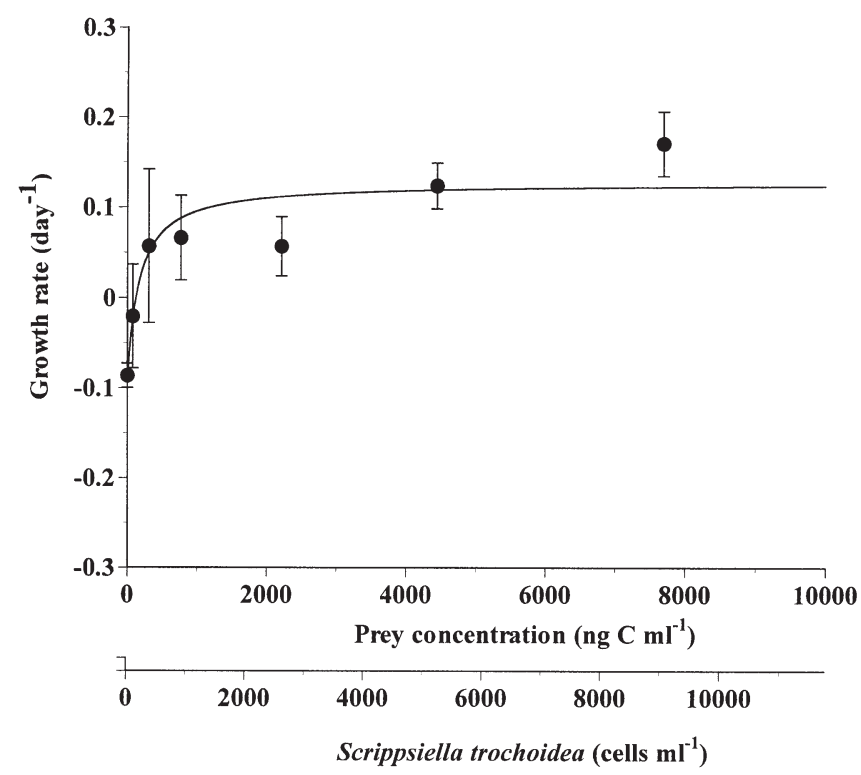

Fig. 2. Tiarina fusus. Specific growth rates on Scrippsiella trochoidea as a function of mean prey concentration. Symbols represent treatment means \pm 1 SE. The curves are fitted as in Fig. 1

edrum, Scrippsiella trochoidea, Heterosigma akashiwo, Prorocentrum minimum, Amphidinium carterae, and Heterocapsa triquetra, but did not ingest Prorocentrum micans. T. fusus was able to engulf part of a living Ceratium fusus cell or a fragment of a dead cell,

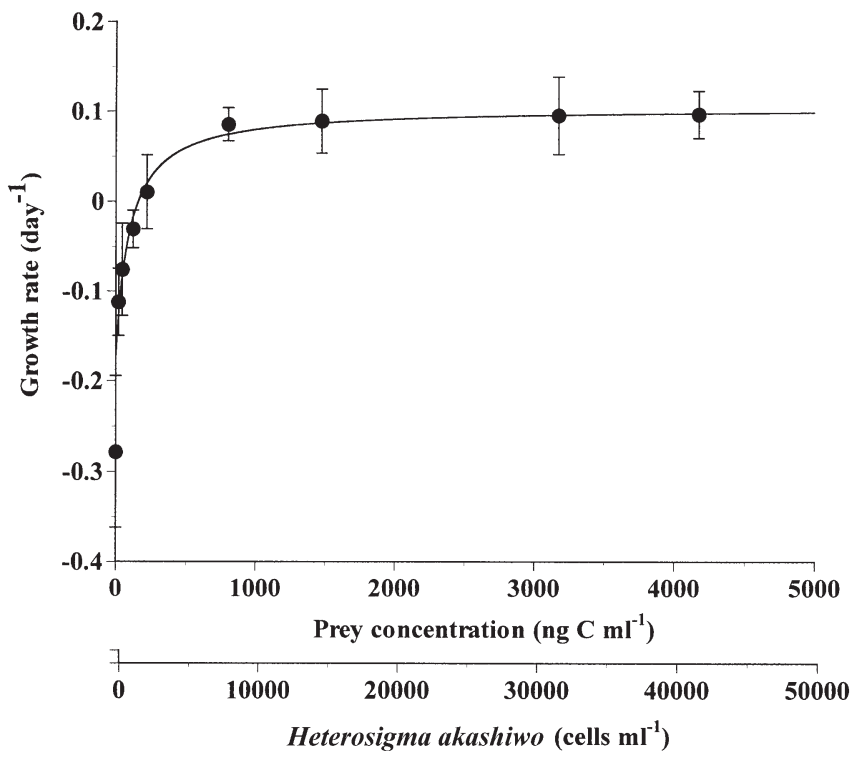

Fig. 3. Tiarina fusus. Specific growth rates on Heterosigma akashiwo as a function of mean prey concentration. Symbols represent treatment means $\pm 1 \mathrm{SE}$. The curves are fitted as in Fig. 1

but could not ingest a whole $C$. fusus because this prey was too long to be included inside the protoplasm of the predator. Between 4 and 5 min after engulfing a single L. polyedrum, T. fusus was able to ingest a second prey item of the same species. A maximum of 7 semi- or almost completely digested L. polyedrum cells were observed inside the protoplasm of individual predators.

\section{Growth rates}

Tiarina fusus grew on Lingulodinium polyedrum, Scrippsiella trochoidea, and Heterosigma akashiwo, but failed to grow on Prorocentrum minimum, Ceratium fusus, Amphidinium carterae, Heterocapsa triquetra, and P. micans (Figs. 1-3, Table 2).

The specific growth rates of Tiarina fusus feeding on unialgal diets of Lingulodinium polyedrum, Scrippsiella trochoidea, and Heterosigma akashiwo increased with increasing mean prey concentration below ca. 500 to $1000 \mathrm{ng} \mathrm{C} \mathrm{ml}^{-1}$, but were saturated or showed only a slight increase at higher prey concentrations (Figs. 1-3). When the data were fitted to Eq. (2), the maximum specific growth rates $\left(\mu_{\max }\right)$ of $T$. fusus on the different diets were $0.471 \mathrm{~d}^{-1}$ for $L$. polyedrum, 0.127 for $S$. trochoidea, and 0.104 for $H$. akashiwo (Table 2). Threshold prey concentrations (where net growth $=0$ ) were $34(14), 121$ (142), and $160 \mathrm{ng} \mathrm{C} \mathrm{ml}^{-1}$ (1600 cells $\mathrm{ml}^{-1}$ ) for L. polyedrum, $S$. trochoidea, and $H$. akashiwo, respectively (Table 2). 
Table 2. Tiarina fusus growth and grazing data. Parameters are for numerical and functional response from Eqs. (2) \& (3) as presented in Figs. 1-6. $\mu_{\max }$ (maximum growth rate, $\mathrm{d}^{-1}$ ), $K_{\mathrm{GR}}$ (prey concentration sustaining $0.5 \mu_{\max }, \mathrm{ng} \mathrm{C} \mathrm{ml}^{-1}$ ), $x^{\prime}$ (threshold prey concentration, $\mathrm{ng} \mathrm{C} \mathrm{ml}^{-1}$ ), $I_{\max }$ (maximum ingestion rate, $\mathrm{ng} \mathrm{C}$ Tiarina $^{-1} \mathrm{~d}^{-1}$ ), $K_{\mathrm{IR}}$ (prey concentration sustaining $0.5 I_{\max }, \mathrm{ng} \mathrm{C} \mathrm{ml}^{-1}$ )

\begin{tabular}{|c|c|c|c|c|c|c|c|c|}
\hline Fig. & Species & $\mu_{\max }$ & $K_{\mathrm{GR}}$ & $x^{\prime}$ & $r^{2}$ & $I_{\max }$ & $K_{\mathrm{IR}}$ & $\mathrm{r}^{2}$ \\
\hline $1 \& 4$ & Lingulodinium polyedrum & 0.471 & 101 & 34 & 0.68 & 23.4 & 669 & 0.81 \\
\hline $2 \& 5$ & Scrippsiella trochoidea & 0.127 & 285 & 121 & 0.56 & 10.2 & 6310 & 0.79 \\
\hline $3 \& 5$ & Heterosigma akashiwo & 0.104 & 255 & 160 & 0.65 & 6.5 & 1850 & 0.68 \\
\hline 6 & $\begin{array}{l}\text { Prorocentrum minimum } \\
\text { Ceratium fusus }\end{array}$ & $\begin{array}{l}-0.006^{\mathrm{a}} \\
-0.031^{\mathrm{a}}\end{array}$ & & & & 1.8 & 5170 & 0.40 \\
\hline 6 & Amphidinium carterae & $-0.039^{a}$ & & & & 2.7 & 1430 & 0.46 \\
\hline 6 & $\begin{array}{l}\text { Heterocapsa triquetra } \\
\text { Prorocentrum micans }\end{array}$ & $\begin{array}{l}-0.081^{\mathrm{a}} \\
-0.338^{\mathrm{a}}\end{array}$ & & & & 2.6 & 1180 & 0.58 \\
\hline
\end{tabular}

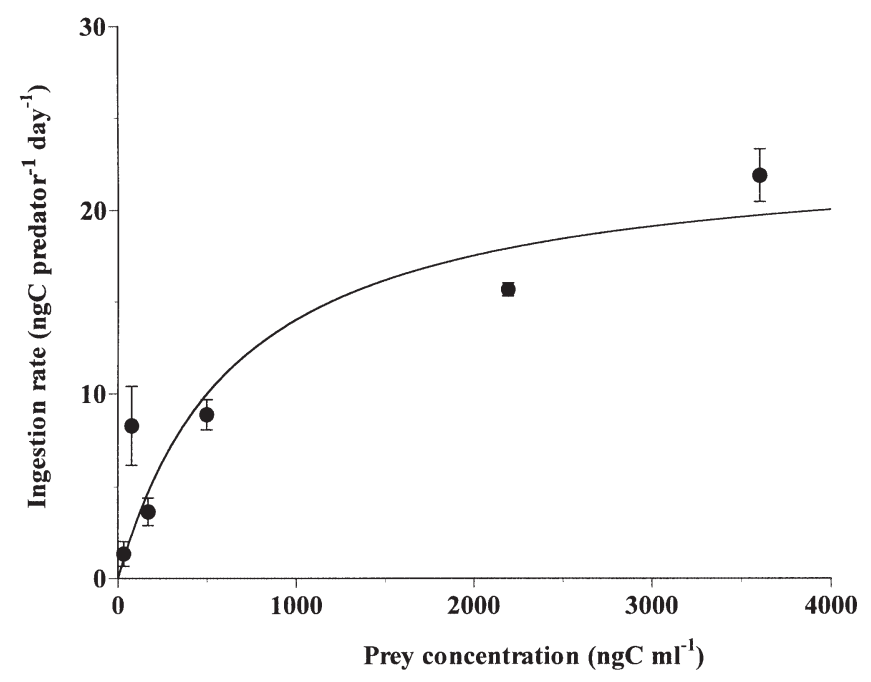

Fig. 4. Tiarina fusus. Ingestion rates on Lingulodinium polyedrum as a function of mean prey concentration. Symbols represent treatment means $\pm 1 \mathrm{SE}$. The curves are fitted by a Michaelis-Menten equation (Eq. 3) using all treatments (see Table 2)

\section{Ingestion and clearance rates}

The ingestion rates of Tiarina fusus on unialgal diets of Lingulodinium polyedrum, Scrippsiella trochoidea, Heterosigma akashiwo, Prorocentrum minimum, and Heterocapsa triquetra increased rapidly with increasing mean prey concentration below ca. 500 to $4000 \mathrm{ng} \mathrm{C} \mathrm{ml}^{-1}$ and slowly, but continuously, increased at higher prey concentrations (Figs. 4-6). The ingestion rate of $T$. fusus on Amphidinium carterae increased rapidly with increasing mean prey concentrations up to ca. $3000 \mathrm{ng} \mathrm{C} \mathrm{ml}^{-1}$, but showed a slight decrease at a higher prey concentration (Fig. 6). When the data were fitted to Eq. (3), the maximum ingestion rates of $T$. fusus in ng $\mathrm{C}$ predator ${ }^{-1} \mathrm{~d}^{-1}$ (and prey cells predator $^{-1} \mathrm{~d}^{-1}$ ) were 23.4 (9.4), 10.2 (12), 6.5 (65), 1.8

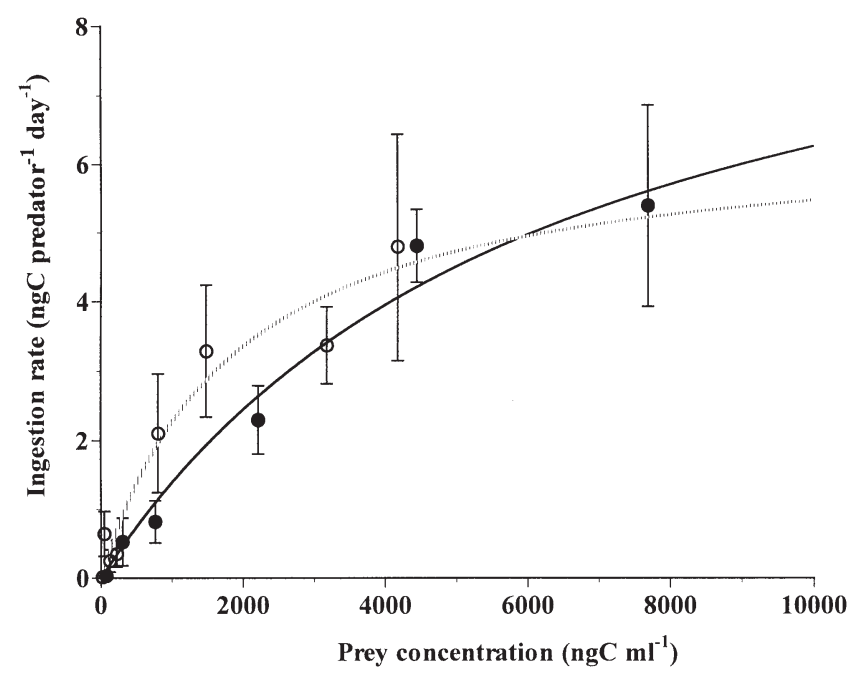

Fig. 5. Tiarina fusus. Ingestion rates on Scrippsiella trochoidea (•) and Heterosigma akashiwo (O) as a function of mean prey concentration. Symbols represent treatment means $\pm 1 \mathrm{SE}$. The curves for $S$. trochoidea (solid line) and H. akashiwo (dashed line) are fitted as in Fig. 4

(12), 2.7 (10.8), and 2.6 (17) for L. polyedrum, S. trochoidea, H. akashiwo, P. minimum, A. carterae, and $H$. triquetra, respectively (Table 2 ).

Maximum clearance rates of Tiarina fusus were $4.5 \mu$ predator $^{-1} \mathrm{~h}^{-1}$ for Lingulodinium polyedrum, 0.6 for Heterosigma akashiwo, 0.2 for Scrippsiella trochoidea and Prorocentrum minimum, 0.1 for Amphidinium carterae, and 0.01 for Heterocapsa triquetra.

\section{Attack ratio and successful capture}

Tiarina fusus had a significantly higher attack ratio on Lingulodinium polyedrum (mean \pm SE: $53 \pm 13 \%$ ) than on Prorocentrum micans (0\%) (1-tailed $t$-test, p < 0.01), but not significantly higher than on Scrippsiella 


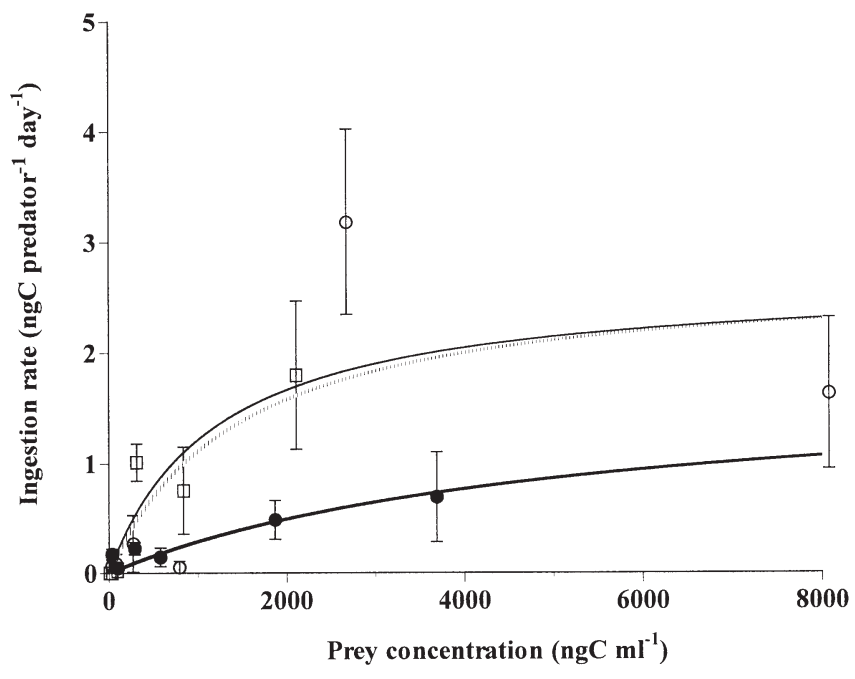

Fig. 6. Tiarina fusus. Ingestion rates on Prorocentrum minimum (•) and Amphidinium carterae (0), and Heterocapsa triquetra ( $\square$ ) as a function of mean prey concentration. Symbols represent treatment means \pm 1 SE. The curves for $P$. minimum (thick solid line), A. carterae (dashed), and $H$. triquetra (thin solid line) are fitted as in Fig. 4

trochoidea $(47 \pm 17 \%)(p>0.1)$ (Fig. 7A). The attack ratio on $S$. trochoidea was significantly higher than on $P$. micans $(\mathrm{p}<0.01)$. Similarly, capture success on $L$. polyedrum $(100 \%)$ was significantly higher than on $S$. trochoidea $(33 \pm 8 \%)(p<0.01)$ (Fig. 7B).

\section{Swimming speed}

The average $( \pm \mathrm{SE})$ and maximum swimming speeds of Tiarina fusus, $1353( \pm 140)$ and $3125 \mu \mathrm{m} \mathrm{s}^{-1}$, respectively, were much greater than those of Heterocapsa triquetra, $370( \pm 14)$ and 496, Heterosigma akashiwo, $211( \pm 9)$ and 299 , or the other prey species offered in the present study (Jeong et al. 1999b).

\section{DISCUSSION}

\section{Prey species}

Few previous studies have considered prey species of Tiarina fusus (Hansen 1991, Nielsen 1991), with Dinophysis sp., Heterocapsa triquetra, and Ceratium furca reported to be eaten by this ciliate. Among the algal prey offered in the present study, $T$. fusus ingested Lingulodinium polyedrum, Scrippsiella trochoidea, Heterocapsa triquetra, Prorocentrum minimum, Amphidinium carterae, Heterosigma akashiwo, and pieces of Ceratium fusus. Therefore, $T$. fusus has diverse prey species.

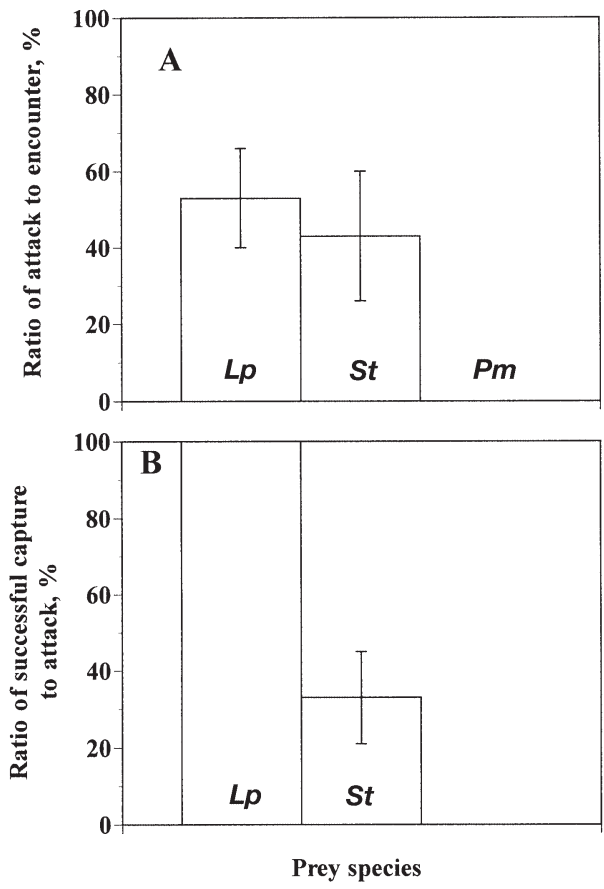

Fig. 7. Tiarina fusus. Ratios (\%) of attack on Lingulodinium polyedrum $(L p)$, Scrippsiella trochoidea $(S t)$, and Prorocentrum micans (Pm) relative to encounter (A) and of successful capture relative to attack (B). Values are treatment means $\pm 1 \mathrm{SE}$

Only a few heterotrophic protists are known to feed on Heterosigma akashiwo, a raphidophyte that can cause large-scale mortalities of fish when forming red tides (Honjo 1993). For example, the heterotrophic dinoflagellate Gyrodinium dominans can grow on $H$. akashiwo (Nakamura et al. 1995). However, the large tintinnid ciliate Favella spp. did not ingest this prey (Taniguchi \& Takeda 1988), or ingestion rate was undetectable even though this prey was ingested during the initial incubation (Kamiyama \& Arima 2001). Therefore, Tiarina fusus is one of a few protistan grazers so far reported to grow and/or prey on H. akashiwo.

Smetacek (1981) reported that Tiarina fusus was abundant when Ceratium fusus dominated the phytoplankton assemblage. We found that $T$. fusus could engulf part of a living $C$. fusus cell or pieces of broken cell, but could not ingest whole cells. Therefore, during the bloom dominated by $C$. fusus, $T$. fusus might grow by feeding on portions of living Ceratium cells and pieces of dead Ceratium cells, or by ingesting other cooccurring prey species.

Data from this study show that maximum growth and ingestion rates of Tiarina fusus are positively correlated with prey cell volume (Fig. 8A,B). This relationship suggests that prey cell volume generally has an effect on growth and ingestion of T. fusus on RTA. However, growth and ingestion rates of $T$. fusus on Scrippsiella 
trochoidea were much higher than those for Prorocentrum micans or Ceratium fusus, even though those prey are similar in cell volume. In addition, growth and ingestion rates of $T$. fusus on smaller Heterosigma akashiwo were also much higher than on larger Prorocentrum minimum, Heterocapsa triquetra, and Amphidinium carterae. Thus, factors other than prey volume may in some cases be important to the feeding activity of T. fusus. Interestingly, like the heterotrophic dinoflagellate Polykrikos kofoidii (Jeong et al. 2001a), T. fusus had a significantly higher attack ratio (number of attempted captures/number of physical contacts) when feeding on $S$. trochoidea than when feeding on $P$. micans. These observations suggest that $S$. trochoidea may be more attractive to $T$. fusus as prey than $P$. micans.

\section{Growth and ingestion}

Maximum ingestion rates $\left(I_{\max }\right)$ of Tiarina fusus on red-tide dinoflagellates obtained in this study are com-
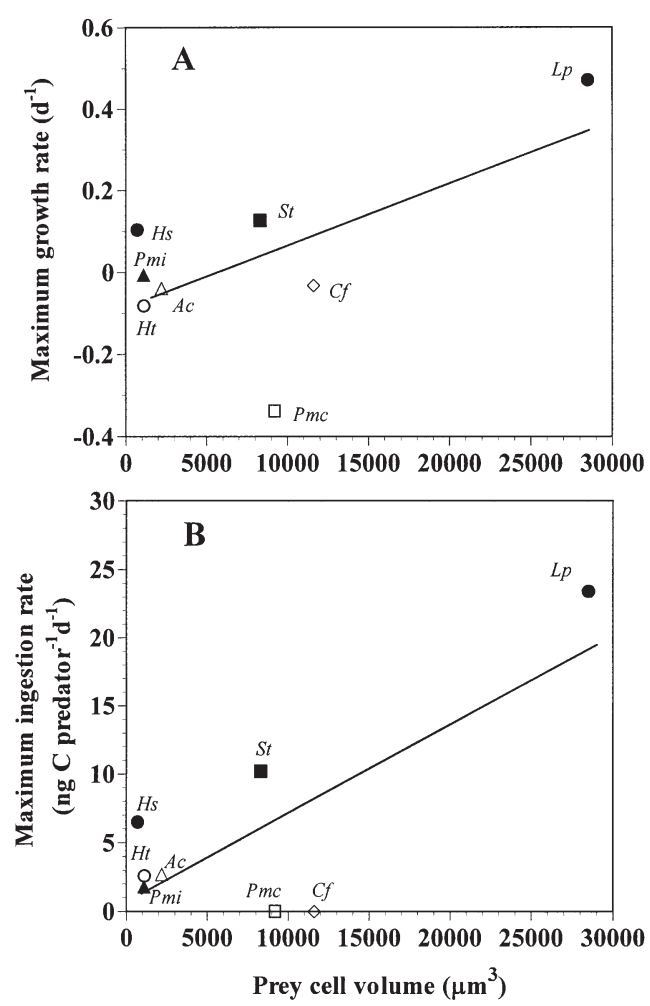

Fig. 8. Tiarina fusus. (A) Maximum growth $\left(\mu_{\max }\right)$ and (B) ingestion $\left(I_{\max }\right)$ rates on 8 red-tide algal prey as a function of prey cell volume (pcv). The equations of the linear regression were (A) $\mu_{\max }\left(\mathrm{d}^{-1}\right)=1.5 \times 10^{-5}(\mathrm{pcv})-9.2 \times 10^{-2}, \mathrm{R}^{2}=0.38$, and (B) $I_{\max }\left(\mathrm{ngC}\right.$ predator $\left.\mathrm{d}^{-1}\right)=6.4 \times 10^{-4}(\mathrm{pcv})+0.86, \mathrm{R}^{2}=0.59$. Ac: Amphidinium carterae, Cf: Ceratium fusus, Ha: Heterosigma akashiwo, Ht: Heterocapsa triquetra, Lp: Lingulodinium polyedrum, Pmc: Prorocentrum micans, Pmi: P. minimum, St: Scrippsiella trochoidea parable to or higher than those previously reported for a mixotrophic dinoflagellate and heterotrophic dinoflagellates, but lower than those for larger ciliates on the same prey (see Table 3). For example, the $I_{\max }$ of T. fusus on Lingulodinium polyedrum is similar to that of Polykrikos kofoidii, higher than that of Fragilidium cf. mexicanum, Protoperidinium cf. divergens, and $P$. crassipes, but much lower than that of Strombidinopsis sp. when corrected to $19^{\circ} \mathrm{C}$ using $Q_{10}=2.8$ (Hansen et al. 1997). The $I_{\max }$ of $T$. fusus on Scrippsiella trochoidea is slightly lower than that for $P$. kofoidii, but much lower than those for Strombidinopsis sp. or Favella sp. This evidence suggests that raptorial feeding on prey directly captured by the narrow, but flexible ciliated mouth (T. fusus) is a similarly effective feeding mechanism to engulfing prey captured by a tow filament $(P$. kofoidii), more effective than pallium feeding on prey captured by a tow filament (Protoperidinium spp.), but less effective than engulfing prey using rows of cilia near the mouth (Strombidinopsis spp. and Favella spp.).

The maximum growth rate of Tiarina fusus on Lingulodinium polyedrum is much lower than that of Polykrikos kofoidii when corrected to $19^{\circ} \mathrm{C}$ using $Q_{10}=$ 2.8 (Hansen et al. 1997) (Table 3), while the $I_{\max }$ of the former predator was similar to that of the latter predator. The average and maximum swimming speeds of $T$. fusus, 1353 and $3125 \mu \mathrm{m} \mathrm{s}^{-1}$, respectively, are much higher than those of $P$. kofoidii (657 and $911 \mu \mathrm{m} \mathrm{s}^{-1}$, respectively) (Jeong et al. 2001a). Thus, greater energy loss due to higher swimming speed of $T$. fusus relative to $P$. kofoidii might account for differences in growth rates.

\section{Grazing impact}

Natural abundances of Tiarina fusus range from 0 to 34500 cells ml ${ }^{-1}$ in coastal marine waters (Smetacek 1981, Dale \& Dahl 1987, Dale 1988, Nielsen 1991, Nomura et al. 1992, Nielsen \& Kiørboe 1994, F. Reid unpubl. data, authors' unpubl. data). However, the grazing impact by $T$. fusus on RTA is difficult to assess due to the lack of data on the abundances of this predator and its co-occurring prey. Grazing coefficients attributable to T. fusus on predominant cooccurring RTA, calculated by combining field data on abundances of T. fusus and co-occurring RTA with laboratory data on ingestion rates obtained in the present study, are 0.0004 to $0.23 \mathrm{~d}^{-1}$ (i.e. 0.04 to $26 \%$ of RTA populations were removed by a Tiarina population $\mathrm{d}^{-1}$ ) (Table 4). In particular, the grazing coefficient of $T$. fusus on Heterosigma akashiwo in Korean coastal waters (maximum density $=8$ Tiarina $\mathrm{ml}^{-1}$ ) is $0.23 \mathrm{~d}^{-1}$, and thus $T$. fusus may sometimes have a considerable 
Table 3. Comparison of growth, ingestion and clearance rates of Tiarina fusus and other protists on the same red-tide algal prey. Rates are corrected to $19^{\circ} \mathrm{C}$ using $Q_{10}=2.8$ (Hansen et al. 1997). PV: predators' volume as $\times 10^{3} \mu m^{3} ; \mu_{\text {max }}$ : maximum growth rate, $\mathrm{d}^{-1} ; I_{\max }$ : maximum ingestion rate, ng C predator ${ }^{-1} \mathrm{~d}^{-1} ; C_{\max }$ : maximum clearance rate, $\mu \mathrm{l}$ predator ${ }^{-1} \mathrm{~h}^{-1} ; \mathrm{NC}$ naked ciliate; TC: tintinnid ciliate; HD: heterotrophic dinoflagellate; MD: mixotrophic dinoflagellate

\begin{tabular}{|llrrrrl}
\hline \multirow{2}{*}{ Prey species } & \multicolumn{1}{c}{ Predator } & PV & $\mu_{\max }$ & $I_{\max }$ & $C_{\max }$ & Source \\
\hline Lingulodinium polyedrum & Tiarina fusus (NC) & 23 & 0.47 & 23 & 4.5 & This study \\
& Polykrikos kofoidii (HD) & 43 & 0.83 & 24 & 5.9 & Jeong et al. (2001a) \\
& Protoperidinium cf. divergens (HD) & 119 & 0.48 & 12 & 0.7 & Jeong \& Latz (1994) \\
& Protoperidinium crassipes (HD) & 204 & 0.31 & 5 & 0.5 & Jeong \& Latz (1994) \\
& Fragilidium cf. mexicanum (MD) & 85 & 0.26 & 7 & 4.0 & Jeong et al. (1999a) \\
& Strombidinopsis sp. (NC) & 560 & 0.83 & 222 & 110 & Jeong et al. (1999b) \\
Scrippsiella trochoidea & Tiarina fusus (NC) & 23 & 0.13 & 10 & 0.1 & This study \\
& Polykrikos kofoidii (HD) & 43 & 0.97 & 17 & 1.1 & Jeong et al. (2001a) \\
& Strombidinopsis sp. (NC) & 560 & 0.67 & 207 & 41 & Jeong et al. (1999b) \\
& Favella sp. (TC) & & & 237 & 43 & Stoecker et al. (1981) \\
& & & & & \\
\end{tabular}

Table 4. Estimation of grazing impact by a Tiarina population on a red-tide and/or toxic algae population using the equations in Figs. 4-6 and the abundances of T. fusus and RTA. PIR: population ingestion rate (prey eaten $\left.\mathrm{ml}^{-1} \mathrm{~d}^{-1}\right) ; g$ : grazing coefficient $\left(\mathrm{d}^{-1}\right)$

\begin{tabular}{|c|c|c|c|c|c|c|}
\hline $\begin{array}{l}\text { Predator } \\
\text { (Tiarina) }\end{array}$ & Prey species & $\begin{array}{l}\text { Predator density } \\
\quad\left(\text { cells } \mathrm{ml}^{-1}\right)\end{array}$ & $\begin{array}{l}\text { Prey density } \\
\left(\text { cells ml }{ }^{-1}\right)\end{array}$ & PIR & $g$ & Source \\
\hline \multirow{5}{*}{ T. fusus } & Heterosigma akashiwo & 8.0 & 670 & 138 & 0.230 & Authors' (unpubl. data) ${ }^{a}$ \\
\hline & Prorocentrum minimum & 8.0 & 123 & 2.2 & 0.018 & Authors' (unpubl. data) ${ }^{a}$ \\
\hline & Scrippsiella trochoidea & 0.24 & 260 & 0.104 & 0.0004 & F. Reid (unpubl. data) ${ }^{b}$ \\
\hline & Lingulodinium polyedrum & 0.24 & 3.6 & 0.012 & 0.003 & F. Reid (unpubl. data) ${ }^{b}$ \\
\hline & L. polyedrum & 0.29 & 0.2 & 0.001 & 0.004 & F. Reid (unpubl. data) ${ }^{\mathrm{b}}$ \\
\hline
\end{tabular}

grazing impact on $H$. akashiwo populations. Similarly, T. fusus abundance was highest (12.8 Tiarina $\mathrm{ml}^{-1}$ ) in Tokyo Bay during May, when $H$. akashiwo forms red tides (Nomura et al. 1992, Han \& Furuya 2000). Therefore, $T$. fusus may also play an important role in $H$. akashiwo bloom dynamics in Tokyo Bay. By contrast, the grazing coefficient of $T$. fusus on Lingulodinium polyedrum $\left(0.004 \mathrm{~d}^{-1}\right)$ in a coastal water off southern California, USA, was low due to low abundance of the predator. However, T. fusus had a greater impact on $L$. polyedrum than co-occurring Protoperidinium spp. $\left(0.002 \mathrm{~d}^{-1}\right)$. Clearly, additional studies that provide information on predator and prey abundances in the field are needed to better understand the role of $T$. fusus in the population dynamics of RTA.

Acknowledgements. We thank Dr. Wayne Coats for comments on the manuscript and Freda Reid for allowing us to use her unpublished data. We also thank Seong Taek Kim and Jae Yoon Song for technical support. This paper was funded by grants from the Korea Research Foundation ('99 Brain Korea 21), KOSEF ('99 RRC), and from MOMAF (SooTeuk 2000).

\section{LITERATURE CITED}

Beers JR, Stewart GL (1969) The vertical distribution of microzooplankton and some ecological observations. J Cons Int Explor Mer 33:30-44

Dale T (1988) Oil pollution and plankton dynamics. VI. Controlled ecosystem experiments in Lindaaspollene, Norway, June 1981: effects on planktonic ciliates following nutrient addition to natural and oil-polluted enclosed water columns. Sarsia 73:179-191

Dale T, Dahl E (1987) A red tide in southern Norway caused by mass occurrence of the planktonic ciliate Tiarina fusus. Fauna 40:98-103

ECOHAB (1995) The ecology and oceanography of harmful algal blooms: a national research agenda. Woods Hole Oceanographic Institute, Woods Hole, MA, p 1-66

Elbrächter M (1973) Population dynamics of Ceratium in coastal waters of the Kiel Bay. Oikos 15:43-48

Eppley RW, Harrison WG (1975) Physiological ecology of Gonyaulax polyedrum, a red tide water dinoflagellate of southern California. In: Locicero VR (ed) Proc 1st Int Conf Toxic Dinoflagellate Blooms. Massachusetts Science and Technology Foundation, Wakefield, MA, p 11-22

Frost BW (1972) Effects of size and concentration of food particles on the feeding behavior of the marine planktonic copepod Calanus pacificus. Limnol Oceanogr 17: 805-815

Guillard RRL, Ryther JH (1962) Studies of marine planktonic 
diatoms. I. Cyclotella nana Hustedt and Detonula confervacea (Cleve) Grun. Can J Microbiol 8:229-239

Han MS, Furuya K (2000) Size and species-specific primary productivity and community structure of phytoplankton in Tokyo Bay. J Plankton Res 22:1221-1235

Hansen PJ (1991) Dinophysis - a planktonic dinoflagellate genus which can act both as a prey and a predator of a ciliate. Mar Ecol Prog Ser 69:201-204

Hansen PJ, Bjornsen PK, Hansen BW (1997) Zooplankton grazing and growth: scaling within the $2-2,000-\mu \mathrm{m}$ body size range. Limnol Oceanogr 42:687-704

Heinbokel JF (1978) Studies on the functional role of tintinnids in the Southern California Bight. I. Grazing and growth rates in laboratory cultures. Mar Biol 47:177-189

Holmes RW, Williams PM, Eppley RW (1967) Red water in La Jolla Bay, 1964-1966. Limnol Oceanogr 12:503-512

Honjo T (1993) Overview on bloom dynamics and physiological ecology of Heterosigma akashiwo. In: Smayda T, Shimizu Y (eds) Toxic phytoplankton blooms in the sea. Elsevier, Amsterdam, p 33-41

Jeong HJ, Latz MI (1994) Growth and grazing rates of the heterotrophic dinoflagellate Protoperidinium spp. on red tide dinoflagellates. Mar Ecol Prog Ser 106:173-185

Jeong HJ, Shim JH, Kim JS, Park JY, Lee CW, Lee Y (1999a) Feeding by the mixotrophic thecate dinoflagellate Fragilidium cf. mexicanum on red-tide and toxic dinoflagellates. Mar Ecol Prog Ser 176:263-277

Jeong HJ, Shim JH, Lee CW, Kim JS, Koh SM (1999b) Growth and grazing rates of the marine planktonic ciliate Strombidinopsis sp. on red-tide and toxic dinoflagellates. J Eukaryot Microb 46:69-76

Jeong HJ, Kim SK, Kim JS, Kim ST, Yoo YD, Yoon JY (2001a) Growth and grazing rates of the heterotrophic dinoflagellate Polykrikos kofoidii on red-tide and toxic dinoflagellates. J Eukaryot Microb 48:298-308

Jeong HJ, Kang HJ, Shim JH, Park JK, Kim JS, Song JY, Choi HJ (2001b) Interactions among the toxic dinoflagellate Amphidinium carterae, the heterotrophic dinoflagellate Oxyrrhis marina, and the calanoid copepods Acartia spp. Mar Ecol Prog Ser 218:77-86

Kamiyama T, Arima S (2001) Feeding characteristics of two tintinnid ciliate species on plankton including harmful species: effects of prey size on ingestion rates and selectivity. J Exp Mar Biol Ecol 257:281-296

Mamaeva NV (1983) Planktonic infusorians of the central part of the Indian Ocean. Sov J Mar Biol 8:254-258

Moiseyev YV (1986) Distribution of protozoans near sea-

Editorial responsibility: David Caron,

Los Angeles, California, USA mounts in the western Indian Ocean. Oceanology 26: $86-90$

Morey-Gaines G (1980) The ecological role of dinoflagellate blooms in the Los Angeles-Long Beach Harbor. PhD thesis, University of Southern California, Los Angeles

Nakamura Y, Suzuki SY, Hiromi J (1995) Growth and grazing of a naked heterotrophic dinoflagellate, Gyrodinium dominans. Aquat Microb Ecol 9:157-164

Nielsen TG (1991) Contribution of zooplankton grazing to the decline of a Ceratium bloom. Limnol Oceanogr 36: 1091-1106

Nielsen TG, Kiørboe T (1994) Regulation of zooplankton biomass and production in a temperate, coastal ecosystem. 2. Ciliates. Limnol Oceanogr 39:508-519

Nomura H, Ishimaru T, Murano M (1992) Microzooplankton assemblage and its seasonal variation in Tokyo Bay, Japan. La Mer 30:57-72

Putt M, Stoecker DK (1989) An experimentally determined carbon:volume ratio for marine 'oligotrichous' ciliates from estuarine and coastal waters. Limnol Oceanogr 34: 1097-1103

Reid FMH, Lange CB, White MM (1985) Microplankton species assemblages at the Scripps pier from March to November 1983 during the 1982-1984 El Nino event. Bot Mar 28:443-452

Sleigh MA, Edwards ES, John AWG, Burkill PH (1996) Microzooplankton community structure in the north-eastern Atlantic: trends with latitude, depth and date, between May and early August. J Mar Biol Assoc UK 76:287-296

Smetacek V (1981) The annual cycle of protozooplankton in the Kiel Bight. Mar Biol 63:1-11

Stoecker DK, Guillard RRL, Kavee RM (1981) Selective predation by Favella ehrenbergii (Tintinnida) on and among dinoflagellates. Biol Bull 160:136-145

Strathmann RR (1967) Estimating the organic carbon content of phytoplankton from cell volume or plasma volume. Limnol Oceanogr 12:411-418

Taniguchi A, Takeda Y (1988) Feeding rate and behavior of the tintinnid ciliate Favella taraikaensis observed with a high speed VTR system. Mar Microb Food Webs 3:21-34

Tumantseva NI, Kopylov AI (1985) Reproduction and production rates of planktic infusoria in coastal waters of Peru. Oceanology 25:390-394

Watras CJ, Garcon VC, Olson RJ, Chishom SW, Anderson DM (1985) The effect of zooplankton grazing on estuarine blooms of the toxic dinoflagellate Gonyaulax tamarensis. J Plankton Res 7:891-908

Submitted: September 7, 2001; Accepted: April 15, 2002

Proofs received from author(s): June 24, 2002 